DOI: 10.17951/en.2019.4.95-110

\begin{tabular}{cc}
\hline & ANNALES \\
& UNIVERSITATIS MARIAE CURIE-SKŁODOWSKA \\
LOL. IV & SECTIO N \\
\hline
\end{tabular}

Sylwia Jaskuła

Państwowa Wyższa Szkoła Informatyki i Przedsiębiorczości w Łomży

ORCID: http://orcid.org/0000-0003-2033-5097

sjaskula@pwsip.edu.pl

\title{
Działania pozorne w ewaluacji w obszarze szkolnictwa wyższego
}

\section{Sham Activities in Evaluation in the Area of Higher Education}

Streszczenie: W polskich warunkach na wielu obszarach ewaluacja odchodzi od ponad stuletnich tradycji społecznych badań stosowanych, których głównym celem jest wspieranie rozwoju. Określenia ewaluacja często się nadużywa, zastępując tym pojęciem inne metody diagnostyczne, takie jak: pomiar, parametryzacja, akredytacja, audyt, ocena. Niesłusznie przypisuje się ewaluacji funkcje kontrolne i biurokratyczne, pomijając jej potencjały animacyjne, uspołeczniające, motywujące czy formatywne. W ten sposób traci ona społeczne zaufanie i przyjmuje formę działań pozornych, a więc takich, które wbrew założeniom nie realizują zakładanych celów ani nie spełniają założonych i określonych jej tożsamością funkcji, choć przebiegają zgodnie z procedurami przyjętymi przez zleceniodawców.

Słowa kluczowe: ewaluacja społeczna; działania pozorne; ewaluacja pozorna; ewaluacja w edukacji; ewaluacja jakości kształcenia 


\section{WPROWADZENIE}

Początki ewaluacji w polskim systemie edukacji podobne są do narodzin badań ewaluacyjnych w szkołach amerykańskich, w których wczesne idee odnosiły się do koncepcji badań ewaluacyjnych opracowanych przez Ralpha W. Tylera. Refleksje „ojca ewaluacji edukacyjnej” zbiegły się z wcześniej opracowanymi koncepcjami Fredericka W. Taylora, zawartymi w jego pracy z 1911 roku pt. Zasady naukowego zarzadzania, a odnoszącymi się do systematycznego i opartego na metodologii naukowej doskonalenia aktywności człowieka w sferze działań przemysłowych. Był on skoncentrowany na opracowywaniu projektów usprawniania procesu produkcyjnego oraz prowadził analizy mające na celu doskonalenie wydajności pracy. Odmienne, bo odwołujące się do obszaru edukacji, koncepcje doskonalenia działań poprzez systematycznie budowane programy nauczania oraz weryfikację ich rezultatów podjął wspomniany wyżej pionier ewaluacji R.W. Tyler ${ }^{1}$. Jego praktyka badawcza, określana mianem badań ewaluacyjnych, dotarła m.in. do szkół. Zaprojektował m.in. metody ewaluacji w odniesieniu do zmiennych eksperymentalnych, które zostały użyte w badaniu „Eight-Year Study"2. Otworzyły one możliwości bardziej alternatywnego myślenia o programach nauczania w amerykańskich szkołach średnich ${ }^{3}$.

W ciągu 100 lat ugruntowywania koncepcji i stałego doskonalenia badań ewaluacyjnych przeszły one ewolucję, przeistaczając się podczas kolejno następujących po sobie czterech generacji, które zostały opisane przez Egona G. Gubę i Yvonne S. Lincoln w pracy Fourth Generation Evaluation ${ }^{4}$. W przyjętej klasyfikacji autorzy wskazali na cechy istotnie różnicujące w poszczególnych generacjach i stanowiące zarazem o meritum samego podejścia do możliwości zastosowania i wykorzystania ewaluacji. Wychodząc poza pierwsze trzy generacje ewaluacji (pomiarową, opisową, decyzyjną) i przechodząc do czwartej generacji, nakreślili koncepcję badań zaangażowanych, wnoszących elementy partycypacji i demokratyzacji.

Zmianom sposobów realizacji badań ewaluacyjnych towarzyszyły zmiany w ich definiowaniu. Dzisiejsze rozumienie ewaluacji przeszło pewien proces

1 Ralph W. Tyler to amerykański pedagog, który wprowadził termin ewaluacja do edukacji, stąd często jest nazywany „ojcem ewaluacji edukacyjnej”.

2 Ogólnokrajowy program badań ewaluacyjnych programów nauczania w szkołach średnich, którym zarządzał R.W. Tyler, z udziałem 30 szkół średnich i 300 szkół wyższych oraz uniwersytetów.

3 R.W. Tyler, E.R. Smith, Appraising and Recording Student Progress, Vol. 3: Adventure in American Education, New York 1942.

4 E.G. Guba, Y.S. Lincoln, Fourth Generation Evaluation, London 1989. 
przeobrażeniowy, a ona sama na przestrzeni wielu lat aplikowana była w rozlicznych funkcjach społecznego i organizacyjnego doświadczania. Doprowadziło to do wyraźnego współcześnie rozpoznania jej zalet i wad, ale nade wszystko do odejścia od wąskich technokratycznych jej wyobrażeń w kierunku zdecydowanej modernizacji i demokratyzacji. Stymulowanie i upowszechnianie obecnie dynamicznego i interaktywnego rozumienia całego procesu ewaluacji wychodzi poza funkcje czysto pomiarowe (ewaluacje pierwszej generacji), opisowe (ewaluacje drugiej generacji) i menedżerskie (ewaluacje trzeciej generacji). Aktualnie należałoby zwrócić uwagę na fakt, że dzisiejsza potrzeba uczestniczenia w procesie ewaluacyjnym osób zaangażowanych w badaną rzeczywistość, z nastawieniem na rozwój ich samoświadomości i skłanianie do refleksji nad wartością własnych działań, została poszerzona o konieczność elastyczności i dostosowywania się ewaluacji do coraz szybciej zmieniającej się rzeczywistości. Istota współczesnego ujęcia ewaluacji wykracza poza klasyczne oraz kluczowe elementy wspomagania, animowania, aktywizowania, regenerowania, uspołeczniania czy podnoszenia świadomości. Dodatkowo wymagane są komponenty elastyczności i bezzwłocznej reakcji ewaluacji (w jej różnych wymiarach) na zmiany w taki sposób, aby współtowarzyszyć żywiołowości coraz częściej i szybciej pojawiających się modyfikacji i przekształceń.

\section{POLSKIE DOŚWIADCZENIA ROZWOJU EWALUACJI W EDUKACJI W KIERUNKU DZIAŁAŃ POZORNYCH}

Doświadczenia analogiczne do badań ewaluacyjnych istnieją w polskiej tradycji badań społecznych od dawna, tylko nie stosowano do nich terminu ewaluacja i nie wdrażano ich w systemy decyzyjne. Pojęciem tym zaczęto określać badania wartościujące w Polsce dopiero w połowie lat 90. XX wieku. Pierwsze zindywidualizowane próby włączenia do szkół i placówek wychowawczo-opiekuńczych ewaluacji rozumianej jako uspołecznione badanie określające wartości celowych działań podejmowanych w konkretnych jednostkach były przyjmowane entuzjastycznie. Ze znacznie mniejszą przychylnością został jednak odebrany w 2003 roku projekt masowego wdrażania tych badań jako formy nadzoru pedagogicznego. Umieszczenie ewaluacji w nadzorze pedagogicznym klasyfikowało ją jako rodzaj kontroli, co było dalekie od rozumienia istoty ewaluacji, a nawet dotychczasowej praktyki, coraz szerzej stosowanej w polskich szkołach. Nie pomogły zabiegi zmieniające rozumienie funkcji nadzoru jako wzorca doskonalenia ani tym bardziej umiejscowienie ewaluacji pomiędzy mierzeniem jakości pracy a kontrolą. Z powodu niezrozumienia idei badań ewaluacyjnych we wprowadzonym i obowiązującym rozporządzeniu zastąpiono je mierzeniem jakości pracy szkoły. 
Kolejna próba wdrożenia ewaluacji do edukacji nastąpiła wraz z rozporządzeniem Ministra Edukacji Narodowej i Sportu z dnia 23 kwietnia 2004 roku w sprawie szczegółowych zasad sprawowania nadzoru pedagogicznego, wykazu stanowisk wymagających kwalifikacji pedagogicznych, kwalifikacji niezbędnych do sprawowania nadzoru pedagogicznego, a także kwalifikacji osób, którym można zlecać prowadzenie badań i opracowywanie ekspertyz ${ }^{5}$. Pomimo wielu mankamentów po raz pierwszy w tak szerokim zakresie wprowadzono ewaluację do systemu oświaty polskiej. Ponadto zapowiedziano dość systematyczny proces przeprowadzania badań ewaluacyjnych. Jego słabością było niewątpliwie odległe od przyjętego w tradycji badań ewaluacyjnych rozumienie samego terminu ewaluacja, a także nieporozumienia związane z metodologia jej przeprowadzania.

Rozporządzenie Ministra Edukacji Narodowej z dnia 7 października 2009 roku w sprawie nadzoru pedagogicznego ${ }^{6}$ ponownie wprowadziło do praktyki szkolnej ewaluację. Niestety, w wymiarze metodologicznym zaproponowany w rozporządzeniu model ewaluacji zbliżył ją do akredytacji w sposób naruszający tożsamość tej pierwszej. Dwukrotna modyfikacja zapisów tego rozporządzenia, w efekcie zmieniająca sens badań i przybliżająca je do badań ewaluacyjnych, nie spowodowała jednak wykluczenia ich z nadzoru pedagogicznego, a tym samym utrzymano ich status kontrolny, co z kolei nadal pozostawało w sprzeczności z istotą ewaluacji oraz jej funkcjami animacyjnymi, interakcyjnymi i rozwojowymi.

Od kilku lat badania ewaluacyjne, podejmowane wcześniej w obszarze polskiej oświaty, rozwijają się w sferze szkolnictwa wyższego. Tu również ewaluacja zagubiła swój prorozwojowy sens i funkcje, zamieniając się w działania o charakterze parametryzacyjnym. Pewien wpływ na to miały naciski sprawozdawcze i administracyjne towarzyszące pojawieniu się Uczelnianych Systemów Zapewniania Jakości Kształcenia. Nie oznacza to, że badania te nie były realizowane w innym, analogicznym formacie, lecz skala zainteresowania i wykorzystywania ewaluacji, z uwzględnieniem właściwych jej ról, była znikoma. Obecnie nie bez znaczenia jest fakt, że ewaluacja pojawia się jako element towarzyszący działaniom powiązanym z doskonaleniem jakości kształcenia ${ }^{7}$. O ile truizmem jest przekonanie o konieczności zapewnienia wysokiej jakości w szkolnictwie wyższym, o tyle konieczna wydaje się refleksja nad rozumieniem, przeprowadzaniem i wykorzystywaniem ewaluacji w uczelniach wyższych, które posługują się nomenklaturą ewaluacyjną w sposób daleki od systematyczności, a także odniesienia jej do przyjętych w tej

5 Dz.U. 2004, nr 89, poz. 845.

6 Dz.U. 2009, nr 168, poz. 1324.

7 Por. Szkota wyższa w toku zmian. Diagnozy i konstatacje, red. J. Kostkiewicz, A. Domagała-Kręcioch, M.J. Szymański, Kraków 2011. 
dziedzinie standardów. W polskim systemie szkolnictwa wyższego ewaluacja jest tematem wciąż nowym w stosunku do ponad stuletniej tradycji i rozwoju kultury ewaluacyjnej w krajach anglosaskich. Jej stosowanie jest często uproszczone, a jednocześnie odbiera badaniom ewaluacyjnym kluczowe funkcje, które mogą być istotne w kontekście misji, zadań i ról uczelni. Podobnie jak w oświacie, w szkolnictwie wyższym jest to powiązane z redukcją metodologii ewaluacji oraz - jeśli nie przede wszystkim - jej rozumienia, zawężającego jej sens do oceny, akredytacji, pomiaru, kontroli czy monitoringu.

Akceptacja badań ewaluacyjnych, które nie wiążą się z rzeczywistą aplikacją całości procesu ewaluacyjnego i rzeczywistym stosowaniem jej metod oraz uspołecznianiem projektowania i przebiegu, generuje zagrożenie, że przyjmą one postać działań pozornych. Pozorność stosowania ewaluacji obniża jej właściwą wartość, pozbawiając kluczowych funkcji. Tym samym ewaluacja staje się przedsięwzięciem „rytualnym”. Należy ją wykonać i potraktować jako konieczny element szerszego działania, które musi się odbyć, ale nic więcej nie musi z tego wynikać.

Modelowo tak rozumiane i stosowane badania ewaluacyjne przypominaja opisane już w latach 70. koncepcje działań pozornych. Sam termin działania pozorne odwołuje się do koncepcji teoretycznej opracowanej przez Jana Lutyńskiego w kontekście systemu monocentrycznego ${ }^{8}$. Wydaje się, że pojęcie to może być nadal użyteczne do opisu i wyjaśniania zjawisk zachodzących we współczesnych organizacjach oraz powiązanych z nimi form życia społecznego, choć wprowadzono je do języka socjologii w latach 70. w celu opisania rzeczywistości tzw. rozwiniętego socjalizmu.

Próbując zdefiniować, czym są działania pozorne, można zastąpić je określeniami: działania fikcyjne, działania efemerydalne czy działania rytualne. Działania pozorne zostały przez J. Lutyńskiego określone jako czynności, które ze względu na swoje najważniejsze cechy są inne, niż na to wyglądają. Nie realizują one założonych celów ani nie spełniają założonych funkcji, ale przebiegają zgodnie z zamierzeniami wykonawców i w zgodzie $\mathrm{z}$ formalnie respektowanymi procedurami. Jan Lutyński w swoich artykułach poświęconych działaniom pozornym przedstawił ich rozumienie, funkcje, odmiany oraz mechanizmy je wywołujące. Ich sens scharakteryzował, opisując sześć cech:

- oficjalnie działania pozorne uznawane są za istotne dla realizacji ważnego społecznie celu,

- faktycznie działania te celu tego nie realizują bądź nie przyczyniają się do jego realizacji,

8 J. Lutyński, Działania pozorne, „Kultura i Społeczeństwo” 1977, nr 2; idem, Nauka i polskie problemy. Komentarz socjologa, Warszawa 1990. 
- wszyscy lub prawie wszyscy w danym systemie wiedzą o nieprzydatności tych działań do realizacji danego celu,

- wiedza ta jest wiedzą prywatną, a nie publiczną,

- występowanie tych działań jest konsekwencją przypisania im istotnej roli $\mathrm{w}$ formalnej realizacji danego celu, ich funkcja polega zatem zawsze na samym tylko istnieniu, bez względu na stopień ich fikcyjności,

- fikcja tych działań jest ukrywana ze względu na jakiś rodzaj nacisku.

Mimo że działania pozorne przyczyniają się w sposób fikcyjny do osiągnięcia i zrealizowania postawionych celów, to efekty, jakie wywołują, są realne i przeważnie wiążą się z negatywnymi rezultatami. Według J. Lutyńskiego skutkiem działań pozornych może być obniżenie moralności postaw społecznych i podważenie wiary w autentyczność istotnych społecznie wartości. Ponieważ wszyscy uczestnicy działań pozornych zdają sobie sprawę z ich fikcyjności, usprawiedliwiają tym swoją obojętność i brak zaangażowania, rozpowszechniając wzorzec „bylejakości”.

Niestety, stosunkowo niewielkie doświadczenia związane z badaniami ewaluacyjnymi w polskim systemie edukacyjnym, nacisk instytucjonalny na ich realizację bez stosownego przygotowania i systemu kształcenia oraz silna biurokratyzacja formalnych systemów edukacji stwarzają bardzo poważne zagrożenie działaniami pozornymi, zarówno w istniejących, jak i w projektowanych formach ewaluacji. Negatywne konsekwencje działań pozornych w badaniach ewaluacyjnych ze szczególną siłą dotykają ewaluacji społecznej, która animuje potencjał interakcyjny, krytyczny i refleksyjny procesu ewaluacyjnego, eksponując jego dynamiczny, rozwojowy charakter. Wszelkie pozorowanie działań jest szczególnie destrukcyjne, gdyż zakłada coś więcej niż reprodukcję działań, umiejętności i kompetencji już istniejących. Uniemożliwia ono realne wartościowanie konkretnych działań, a także realne zarządzanie przebiegiem procesów, które zakładają rozpoznanie i wolę aktualizacji potencjałów rozwojowych na poziomie osobowym oraz wspólnotowym i organizacyjnym ${ }^{10}$.

\section{EWALUACJA W USTAWIE 2.0}

Ustawa z dnia 20 lipca 2018 roku - Prawo o szkolnictwie wyższym i nauce ${ }^{11}$ wprowadziła działania określane jako ewaluacja jakości kształcenia, ewaluacja szkół doktorskich i ewaluacja jakości działalności naukowej. Ponieważ przedmiotem ewaluacji mogą być tylko działania celowe, posiadające określone granice

9 Idem, Nauka..., s. 105-120.

10 S. Jaskuła, Ewaluacja społeczna w edukacji, Kraków 2018, s. 88-92.

11 Dz.U. 2018, poz. 1668. 
i zasięg, można przyjąć, że określenie ewaluacja jakości ksztatcenia oznacza przeprowadzanie badań ewaluacyjnych w odniesieniu do działań mających na celu podnoszenie jakości kształcenia na uczelniach wyższych, ewaluacja szkót doktorskich to ewaluacja działań podejmowanych w ramach procesów kształcenia zapewnianych przez szkoły doktorskie, a ewaluacja jakości działalności naukowej to badanie czynności zapewniających i podnoszących jakość działalności naukowej. Brak ścisłości dookreśleń w zapisach tej ustawy sam w sobie nie stanowi błędu, ale pod warunkiem rozumienia konsekwencji takich uproszczeń w praktycznym wdrażaniu metodologii badań. Obawy te rosną wobec faktu, że we wspomnianej ustawie nie tylko nie ma definicji samego pojęcia ewaluacji, lecz także brakuje opisu metodologii jej przeprowadzania. Można więc przypuszczać, że jej twórcy założyli znajomość badań ewaluacyjnych przeprowadzanych przez wykonawców w odniesieniu do aktywności podejmowanych w szkolnictwie wyższym. Jednak dotychczasowe praktyki, a tym bardziej zapisy we wcześniejszych rozporządzeniach, nie wprowadziły ani porządku w rozumieniu, ani jednoznaczności i celowości podejmowanych na podstawie przepisów prawnych badań ewaluacyjnych. Opieranie się na dotychczasowych przepisach umieszczanych $w$ aktach prawnych dotyczących ewaluacji na uczelniach wyższych i wynikających z nich praktyk nie doprowadziło zatem do poprawnego i pełnego uprawiania badań ewaluacyjnych. Zredukowano ich funkcje, a nawet zastąpiono prostym badaniem ankietowym, którego główny cel to określenie poziomu satysfakcji studentów z przeprowadzonych zajęć.

Ustawa Prawo o szkolnictwie wyższym i nauce wprowadziła ewaluację w Dziale VI pt. „Ewaluacja jakości kształcenia, ewaluacja szkół doktorskich i ewaluacja jakości działalności naukowej”. Już w jego Rozdziale 1, poświęconym ewaluacji jakości kształcenia, ewaluacja jest utożsamiana z oceną, a metodologia jej przeprowadzania została zastąpiona metodologią oceniania - art. 241 pkt 2: „Ewaluacji dokonuje się w formie oceny programowej lub oceny kompleksowej”. Należy zaznaczyć, że pierwsza z nich jest cykliczną oceną jakości kształcenia na danym kierunku studiów, druga zaś jest oceną działań na rzecz zapewnienia jakości kształcenia w uczelni, przeprowadzaną na wniosek uczelni, która uzyskała pozytywne oceny programowe lub pozytywną ocenę kompleksową. Dodatkowo ocena programowa lub kompleksowa może być wystawiona na podstawie „oceny, akredytacji lub certyfikatu podmiotu dokonującego ocen jakości kształcenia" (art. 244 pkt 1 ustawy). Tym samym zastąpiono cele i funkcje ewaluacji celami i funkcjami oceny. Ewaluacja jest procesem, którego głównym celem jest określenie wartości danego działania, natomiast ocena jest osądem i pełni głównie funkcje kontrolne. Badania ewaluacyjne, w odróżnieniu od sterujących procedur oceny, zakładają uczestnictwo społeczne na różnych etapach 
ich projektowania i przeprowadzania, dlatego istotnym elementem procesu ewaluacyjnego są interakcje pomiędzy jego uczestnikami. Prowadzony dialog, który ma na celu doskonalenie i rozwój badanych działań, może doprowadzić do lepszego rozumienia badanego przedmiotu. Interaktywność i negocjacyjne podejście do procesu badania (wzajemne oddziaływanie badacza i badanego) stanowią jednocześnie szeroko rozumiany proces uczenia się. Ocena, zwłaszcza parametryczna lub dokonywana według zestandaryzowanej skali, zapewnia porównywalność uzyskanych wyników. W badaniach ewaluacyjnych posługujących się wieloczynnikowym, kontekstualnym, wielowymiarowym i jakościowo zorientowanym modelem analiz często nie ma możliwości dokonywania porównań ze względu na ich indywidualny $i$ kompleksowy charakter. $Z$ tych właśnie powodów ocena jest elementem ewaluacji, a jej zredukowany w procesie parametryzacji charakter czyni z ewaluacji jej własne zaprzeczenie, czyli dekonstrukcję procesu wspierania, animowania i refleksyjności.

Nieporozumieniem metodologicznym jest również zastąpienie ewaluacji akredytacją. Akredytacja to proces sprawdzania stopnia realizacji formalnie określonych dla danej instytucji lub programu standardów, które są opracowane poza środowiskiem akredytowanej instytucji. Jej głównym celem, obok diagnostyki, jest przede wszystkim dyscyplinowanie i kontrola poprzez nadanie oceny wynikającej z ustalonej i zamkniętej skali ocen, która zapewnia porównywalność wyników uzyskanych w różnych instytucjach. Ewaluacja ma charakter znacznie bardziej uwzględniający unikalny, środowiskowy, kontekstualny, a nawet indywidualny wymiar wartościowanych działań, a raport końcowy jest dopasowany do potrzeb bardzo konkretnego odbiorcy. Dlatego wartość badań ewaluacyjnych nie wynika jedynie z końcowego etapu wypracowania wyniku ostatecznego, lecz także przejawia się w całym, częstokroć długim procesie ich realizacji, wychodząc daleko poza wygenerowane ostatecznie rekomendacje, wyniki i konkluzje.

Przy przeprowadzaniu opisywanej w Rozdziale 1 („Ewaluacja jakości kształcenia") oceny programowej brane są pod uwagę następujące elementy określone w ustawie: 1) programy studiów i standardy kształcenia; 2) kadra dydaktyczna i naukowa; 3) infrastruktura wykorzystywana do realizacji programu studiów; 4) współpraca z otoczeniem społeczno-gospodarczym; 5) umiędzynarodowienie; 6) wsparcie studentów w procesie uczenia się (art. 242 pkt 2 ustawy). Ustawodawca określił zatem obszary, które będą podlegać ocenie - ewaluacji. Odgórny dobór tych obszarów do badań ewaluacyjnych nie może jednak eliminować uspołecznionego i określonego potrzebami konkretnego środowiska oraz ich dialogicznego charakteru. Jeszcze silniej podkreśla ten aspekt zapis zamieszczony w art. 248 ustawy, który wyklucza całkowicie środowiskowy kontekst przeprowadzania badań: „Minister właściwy do spraw szkolnictwa 
wyższego i nauki określi, w drodze rozporządzenia, kryteria: 1) oceny programowej, 2) oceny kompleksowej - mając na uwadze międzynarodowe standardy w zakresie zapewniania jakości kształcenia oraz potrzebę zapewnienia właściwych wzorców oceny".

Taki model ewaluacji uniemożliwia realizację głównych jej funkcji - szczególnie tych, które zostały wyeksponowane w ewaluacji czwartej generacji, a które stały się kluczowe w procesie prowadzenia rzetelnych badań. Są to funkcje: uspołeczniająca, animująca oraz dialogiczna. Zapewnia natomiast możliwość porównywania wyników badań, tym samym bliżej jest tak zarysowanej metodzie do akredytacji niż do ewaluacji, tym bardziej że zgodnie z art. 241 pkt 4 ustawy oczekuje się, iż ocena programowa zakończy się wydaniem oceny pozytywnej lub negatywnej. Wynik negatywny oceny jakości kształcenia na kierunku studiów oznacza zaprzestanie prowadzenia studiów na danym kierunku.

Tab. 1. Ewaluacja jakości kształcenia w ustawie z dnia 20 lipca 2018 roku Prawo o szkolnictwie wyższym i nauce

\begin{tabular}{|c|c|c|c|}
\hline \multicolumn{4}{|c|}{ EWALUACJA } \\
\hline \multicolumn{2}{|c|}{$\begin{array}{c}\text { OCENA PROGRAMOWA (CYKLICZNA OCENA } \\
\text { JAKOŚCI KSZTAECENIA NA KIERUNKU } \\
\text { STUDIÓW) }\end{array}$} & \multicolumn{2}{|c|}{$\begin{array}{c}\text { OCENA KOMPLEKSOWA (OCENA } \\
\text { SKUTECZNOŚCI DZIAŁAŃ NA RZECZ } \\
\text { ZAPEWNIENIA JAKOŚCI KSZTAŁCENIA } \\
\text { W UCZELNI) } \\
\end{array}$} \\
\hline \multicolumn{2}{|c|}{$\begin{array}{c}\text { Przeprowadzana z inicjatywy PKA, na } \\
\text { wniosek uczelni lub niezwłocznie na wniosek } \\
\text { ministra }\end{array}$} & \multicolumn{2}{|c|}{$\begin{array}{c}\text { Przeprowadzana na wniosek uczelni } \\
\text { posiadającej wyłącznie pozytywne oceny } \\
\text { programowe albo pozytywną ocenę } \\
\text { kompleksową }\end{array}$} \\
\hline OCENA POZYTYWNA & OCENA NEGATYWNA & OCENA POZYTYWNA & $\begin{array}{l}\text { ODMOWA WYDANIA } \\
\text { OCENY POZYTYWNEJ }\end{array}$ \\
\hline $\begin{array}{c}\text { Wydawana na okres } \\
\text { do } 6 \text { lat }\end{array}$ & - & $\begin{array}{l}\text { Wydawana na okres } \\
\text { od } 3 \text { do } 8 \text { lat }\end{array}$ & - \\
\hline- & $\begin{array}{l}\text { Uczelnia zaprzestaje } \\
\text { prowadzenia studiów } \\
\text { na ocenianym } \\
\text { kierunku } \\
\end{array}$ & - & - \\
\hline
\end{tabular}

Źródło: opracowanie własne.

W Rozdziale 2 analizowanej ustawy, poświęconym ewaluacji szkół doktorskich, określono metodykę przeprowadzania badań ewaluacyjnych jakości kształcenia w szkołach doktorskich. Według zapisów będą one prowadzone przez ekspertów posiadających znaczący dorobek naukowy lub artystyczny, powołanych przez przewodniczącego Komisji Ewaluacji Nauki. Według art. 261 ustawy: „Przy ewaluacji uwzględnia się następujące kryteria: 1) adekwatność programu kształcenia oraz indywidualnych planów badawczych do efektów 
uczenia się dla kwalifikacji na poziomie 8 PRK oraz ich realizację; 2) sposób weryfikacji efektów uczenia się dla kwalifikacji na poziomie 8 PRK; 3) kwalifikacje nauczycieli akademickich lub pracowników naukowych prowadzących kształcenie w szkole doktorskiej; 4) jakość procesu rekrutacji; 5) jakość opieki naukowej lub artystycznej i wsparcia w prowadzeniu działalności naukowej; 6) rzetelność przeprowadzania oceny śródokresowej; 7) umiędzynarodowienie; 8) skuteczność kształcenia doktorantów".

Wszystkie te elementy są niewątpliwie ważne, biorąc pod uwagę dbanie o jakość kształcenia szkół doktorskich, ale tak jak w Rozdziale 1 ustawy nie pozostawiono tu żadnej przestrzeni na uspołecznienie ewaluacji, a także na potrzeby, które wynikają (bądź będą wynikać) ze specyfiki poszczególnych jednostek. Należy bowiem podkreślić, że szczegółowe kryteria jakości kształcenia w szkole doktorskiej oraz sposób jej przeprowadzania określa w drodze rozporządzenia - zgodnie z zapisem w art. 263 ustawy - minister właściwy do spraw szkolnictwa wyższego i nauki.

Wątpliwości budzą też następujące zapisy: „kwalifikacje nauczycieli akademickich lub pracowników naukowych prowadzących kształcenie w szkole doktorskiej” oraz „umiędzynarodowienie”, określone jako kryteria ewaluacji. Kryteria ewaluacji są elementami projektu ewaluacyjnego i określają w ramach postawionych pytań badawczych, jakie wartości są istotne w procesie badawczym w konkretnym środowisku. W art. 261 ustawy istotnymi kryteriami - wartościami dla ustawodawców - są: adekwatność, jakość, rzetelność, skuteczność. Nie jest natomiast określone, jakim kryteriom będą podlegać w procesie badawczym kwalifikacje i umiędzynarodowienie. O ile jednoznacznie wartościuje się programy kształcenia, proces rekrutacji czy przeprowadzanie ocen śródokresowych, o tyle te dwa obszary zostały pozostawione bez określeń, co daje różne możliwości ich interpretacji (w zasadzie dowolnej) przez wyznaczonych ekspertów Komisji Ewaluacji Nauki.

Ewaluacja jakości kształcenia w szkole doktorskiej kończy się oceną pozytywną lub negatywną, wystawianą przez „zespół oceniający”. Ewaluacja jako badanie wspierające rozwój działań od samego początku jej stosowania charakteryzuje się odmiennym do kontroli przebiegiem. Wskazanie słabych punktów, potknięć czy tego, co nie wychodzi, jest w tym typie badania potrzebne do utworzenia ewentualnego programu naprawczego, który poprawi jakość działań. W przypadku kontroli, która kończy się wystawieniem oceny, trudno o samoistne pokazywanie minusów, które obniżają notę, ponieważ każdy typ kontroli wyposażony jest w sankcje formalne lub nieformalne ${ }^{12}$, na co wskazują

12 B. Szacka, Wprowadzenie do socjologii, Warszawa 2003, s. 161. 
teorie kontroli społecznej. Kontrola jako proces standaryzacji lub normalizacji efektów ludzkiej pracy niewątpliwie jest potrzebna w każdej instytucji, lecz aby była skuteczna, musi być zinternalizowana ${ }^{13}$, a to $\mathrm{z}$ kolei jest możliwe w sytuacji jasnych i czytelnych znaczeń przypisywanych podejmowanym działaniom.

Rozdział 3 („Ewaluacja jakości działalności naukowej”) ustawy odnosi się do badań ewaluacyjnych osiągnięć wszystkich pracowników prowadzących działalność naukową. Za kryteria ewaluacji przyjęto w art. 267 faktycznie to, co w projekcie ewaluacyjnym określa się jako obszary badawcze, wyznaczając tym samym zakres planowanych badań: „Podstawowymi kryteriami ewaluacji są: 1) poziom naukowy lub artystyczny prowadzonej działalności; 2) efekty finansowe badań naukowych i prac rozwojowych; 3) wpływ działalności naukowej na funkcjonowanie społeczeństwa i gospodarki".

W art. 267 pkt 2 ustawy określono typowe standardy parametryzacji w odniesieniu do powyższych obszarów, które będą doprecyzowane w drodze rozporządzenia wydanego przez ministra właściwego do spraw szkolnictwa wyższego i nauki. Określą one szczegółowe kryteria i sposób oceny osiągnięć w odniesieniu do wskazanych rodzajów działalności naukowych i artystycznych.

Należy w tym miejscu zaznaczyć, że Dział VI „Ewaluacja jakości kształcenia, ewaluacja szkół doktorskich i ewaluacja jakości działalności naukowej" ustawy z dnia 20 lipca 2018 r. - Prawo o szkolnictwie wyższym i nauce, który zapowiada wprowadzenie ewaluacji do szkolnictwa wyższego, budzi wiele wątpliwości. Jego zapisy nie do końca przekonują, że rzeczywiście w ich ramach planowane jest przeprowadzenie badania ewaluacyjnego. Znacznie więcej jest odniesień do oceny, parametryzacji czy kontroli. Tych zastrzeżeń, niestety, nie niweluje opracowany przez Zespół Departamentu Nauki MNiSW przewodnik po ewaluacji jakości kształcenia. Już samo wprowadzenie „Czemu służy system ewaluacji naukowej” miesza pojęcia ewaluacji z oceną, parametryzacją i pomiarem. Jego autorzy powołują się na brytyjski system oceny „Research Assessment Exercise” z 1986 roku jako system ewaluacji nauki. Warto zauważyć, że termin assessment zachowuje w stosunku do pojęcia ewaluacji dość istotną odrębność, której w literaturze diagnostycznej, a zwłaszcza ewaluacyjnej, poświęcono wiele uwagi, bardzo świadomie odróżniając te pojęcia, podobnie jak termin kategoryzacja.

Początki kategoryzacji jednostek naukowych w Holandii sięgają również lat osiemdziesiątych ubiegłego wieku, a obecna ocena działalności naukowej holenderskich jednostek naukowych (Standard Evaluation Protocol) jest przeprowadzana co 6 lat. Kategoryzacja jednostek naukowych jest przeprowadzana w wielu

13 P. Sztompka, Socjologia. Analiza społeczeństwa, Kraków 2002, s. 409. 
współczesnych państwach europejskich, w tym np. we Francji, w Portugalii, w Szwecji i w Rumunii ${ }^{14}$.

Podobnie wymienione $\mathrm{w}$ przewodniku tzw. generacje $\mathrm{e}^{15}$ polskiej ewaluacji budzą zastrzeżenia co do tego, czy opisują ewolucję badań ewaluacyjnych na gruncie szkolnictwa wyższego. Wnikliwie przeprowadzona analiza historii rozporządzeń na pewno pokazuje rozwój metod oceny jednostek naukowych poprzez pomiar, ocenę parametryczną i ankiety oceniające. Mimo że przewodnik poprawnie wskazuje podmiot i przedmiot ewaluacji, co - jak pokazują dotychczasowe polskie doświadczenia, np. na gruncie oświaty - nie zawsze było prawidłowo określane ${ }^{16}$, to jednak zamienia obszary z projektu ewaluacyjnego na kryteria. Ten duży błąd metodologiczny zostaje dodatkowo wzmocniony efektem przypisania do każdego z „kryterium-obszaru” parametrów pomiaru, co jednoznacznie zmienia sens badania z ewaluacji na pomiar kończący się oceną, której przypisana jest w każdym z trzech przypadków waga:

1. Poziom naukowy i artystyczny prowadzonej działalności naukowej, mierzony według trzech parametrów szczegółowych: 1) artykuły naukowe, 2) monografie naukowe, 3) patenty na wynalazki, prawa ochronne na wzory użytkowe i wyłączne prawa hodowców do odmian roślin - waga 70.

2. Efekty finansowe badań naukowych i prac rozwojowych, mierzone według trzech parametrów: 1) projekty finansowane w trybie konkursowym - przez instytucje zagraniczne, organizacje międzynarodowe, przez MNiSW w ramach Narodowego Programu Rozwoju Humanistyki oraz przez NCN i NCBiR, 2) komercjalizacja wyników badań naukowych lub prac rozwojowych, 3) usługi badawcze świadczone na zlecenie podmiotów nienależących do systemu szkolnictwa wyższego i nauki - waga 10.

3. Wpływ działalności naukowej na funkcjonowanie społeczeństwa i gospodarki, mierzony według tylko jednego parametru: opisu wpływu wykazującego związek między najważniejszymi przejawami działalności naukowej w danym podmiocie a gospodarką, ochroną zdrowia, kulturą i sztuką,

14 A. Dańda, B. Szkup, B. Banaszak, P. Wiewiór, Ł. Wawer, M. Rojek, Ewaluacja jakości dziatalności naukowej - przewodnik, https://sum.edu.pl/images/wiadomosci18/20181114_PRZEWODNIK_O_EWALUACJI.pdf [dostęp: 10.10.2019], s. 6-7.

15 Termin generacje ewaluacji został wprowadzony przez E.G. Gubę i Y.S. Lincoln w książce Fourth Generation Evaluation, w której autorzy opisali cztery generacje ewaluacji: od generacji pomiaru do generacji procesu, wskazując tym samym na proces ewolucji ewaluacji od zawężonego pomiaru skuteczności działań w kierunku szerokiego, refleksyjnego rozpoznawania ich wartości w kontekście społecznym.

16 Zob. rozporządzenie Ministra Edukacji Narodowej z dnia 7 października 2009 roku w sprawie nadzoru pedagogicznego (Dz.U. 2009, nr 168, poz. 1324). 
ochroną środowiska przyrodniczego, bezpieczeństwem i obronnością państwa lub innymi czynnikami, które wpływają na rozwój cywilizacyjny społeczeństwa - waga $20^{17}$.

\section{ZAKOŃCZENIE}

Kolejne generacje ewaluacji na przestrzeni 100 lat wprowadzały nowe sposoby jej rozumienia, a zarazem stosowania. Wśród wielości definicji ewaluacji i toczących się wokół jej rozumienia polemik jedno jest niepodważalne - rdzeniem pojęcia evaluation jest kategoria wartości (value). Michael Q. Patton, jeden z czołowych współczesnych ewaluatorów, w swojej definicji rozumienia ewaluacji podkreśla istotność owych wartości, twierdząc, że żadna ewaluacja nie może być pozbawiona świadomej koncentracji na rozpoznawaniu, analizie i objaśnianiu wartości. Nie może być zatem mylona z oceną czy pomiarem. Ewaluacja istnieje w konkretnym kontekście społecznym, głęboko wiążąc się z kierunkami jego przekształceń, a więc działań społecznych, stanowiąc często ich bodziec rozwojowy i nie sprowadzając się jedynie do technik pomiaru, analizy i oceny badanej rzeczywistości. Jako systematyczne badanie wartości programów i strategii społecznych ewaluacja staje się dyskursem, dialogiem i negocjacją ${ }^{18}$. Dzieje się tak już w momencie rozpoczęcia procesu ewaluacji, zapoczątkowanego debatą pomiędzy zainteresowanymi stronami w celu ustalenia jej podstawowych elementów, jakimi są nie tylko zasadniczy obiekt, cele, odbiorcy, lecz także kluczowe pytania ewaluacji, kryteria, wskaźniki oraz sposoby wykorzystania uzyskanych wyników badań. Tym samym ewaluacja staje się refleksyjnym rozpoznaniem, a nawet wspieraniem wartości konkretnego działania w wyniku uspołecznionego procesu jako swoistej wartości dodanej, która stanowi o jej ważnych funkcjach. Bardzo często umykają one z pola widzenia nawet specjalistom zajmującym się ewaluacją, choć są doskonale opisane w prawie stuletniej historii badań ewaluacyjnych, a zwłaszcza w eksponowanej od lat 80. XX wieku tzw. ewaluacji czwartej generacji ${ }^{19}$. To w jej ujęciu ewaluacja staje się świadomym procesem zmiany społecznej, a nie jedynie procesem rejestracji i przetwarzania danych. Ten właśnie proces może być mniej lub bardziej demokratyczny, dialogiczny lub przeciwnie - wyalienowany, a nawet destrukcyjny. Świadomość tych własnych cech procesu nakazuje mówić o jego własnej

17 A. Dańda, B. Szkup, B. Banaszak, P. Wiewiór, Ł. Wawer, M. Rojek, op. cit., s. 20-21.

18 L. Korporowicz, Interakcyjna misja ewaluacji, [w:] Ewaluacja w nadzorze pedagogicznym. Konteksty, red. G. Mazurkiewicz, Kraków 2010, s. 33.

19 E.G. Guba, Y.S. Lincoln, op. cit. 
metodologii, a w konsekwencji - o własnej celowości, intencjonalności, która nie jest sprowadzalna do poprawności konkretnych czynności badawczych, ale określa społeczny sens ewaluacji. Fazy procesu ewaluacyjnego nie są w związku z tym arbitralnym posunięciem badacza, lecz muszą wynikać z ogólniejszej strategii socjalizacji wszystkich uczestników procesu skupionych wokół dokonywanych badań jako swoistego impulsu refleksyjności, poznawania siebie i innych, a w końcu - analizy wniosków.

Wiele podejść do rozumienia ewaluacji stanowi o tym, że sam osąd nie jest priorytetem w procesie ewaluacji. Szczególnie odkąd rozwinęła się ewaluacja czwartej generacji coraz większe znaczenie przypisuje się interakcji i animacji, a także dyskusji i negocjacji pomiędzy uczestnikami ewaluacji. Perspektywa postrzegania ewaluacji jako oceny koncentruje uwagę na jednym jej elemencie, pomijając z jednej strony wielość alternatywnych podejść, z drugiej zaś ograniczając sam zakres możliwości jej stosowania i oddziaływania. Jeśli do tego spojrzymy na ewaluację jako na dziedzinę wypracowanej i usystematyzowanej wiedzy, to w tym kontekście trudno byłoby postawić znak równości pomiędzy ewaluacją a oceną i analizować obie te kategorie zamiennie ${ }^{20}$.

Niezależnie od wielu odmiennych sposobów definiowania ewaluacji nie powinna ona być utożsamiana $\mathrm{z}$ oceną, chociaż zawiera w sobie element nadawania wartości danemu przedsięwzięciu. Zasadnicza różnica polega jednak na tym, że ewaluacja jest dziedziną nauki, zespołem koncepcji teoretycznych oraz procesem, w ramach którego analiza podjętych działań dokonywana jest w oparciu o wypracowane standardy i kryteria ewaluacyjne, ocena natomiast stanowi możliwie najbardziej obiektywne zaopiniowanie danego przedsięwzięcia na podstawie osobistych preferencji i wartości. Ponadto ocena jest jednym z elementów tego procesu, przeważnie odnosi się do pojedynczego działania i może być pominięta w procesie ewaluacji - wtedy to akcent położony zostaje na dynamikę interakcji i negocjacji pomiędzy uczestnikami danego przedsięwzięcia ${ }^{21}$.

Polskie szkolnictwo wyższe niewątpliwie potrzebuje różnych metod diagnostycznych sprawdzających i kontrolujących jakość kształcenia, lecz również działań, które będą wskazywać, w jaki sposób tę jakość podnosić. Ustawodawca

20 T. Kierzkowski, Ocena (ewaluacja) programów i projektów o charakterze społeczno-gospodarczym w kontekście przystapienia Polski do Unii Europejskiej, Warszawa 2002, s. 10.

21 K. Ornacka, Procedura ewaluacyjna a standardy ustug w pomocy społecznej: praca socjalna $z$ rodzina dotknięta zjawiskiem przemocy oraz interwencja kryzysowa $w$ rodzinie dotkniętej zjawiskiem przemocy, www.wrzos.org.pl/projekt1.18/download/Ekspertyza\%20ZE\%20PwR.pdf [dostęp: 4.05.2019]. 
słusznie zatem wprowadza badania ewaluacyjne jako element niezbędny w podnoszeniu jakości kształcenia na polskich uczelniach. Warto dodać, że ewaluacja była już wykorzystywana w różnych krajach w obszarze edukacji do doskonalenia procesów nauczania i uczenia. Niewątpliwie tego typu badania mogą pomóc zrozumieć, rozwinąć i ewentualnie skorygować działania wymagające naprawy. Właściwie rozumiana i w konsekwencji dobrze przeprowadzona ewaluacja może być elementem wspierającym rozwój konkretnej szkoły na wszystkich poziomach jej zarządzania: konstruowania misji i strategicznych kierunków rozwoju, profilowania konkretnych kierunków kształcenia, form i treści współpracy środowiskowej i międzynarodowej, rozwoju kadry i kultury akademickiej. Ewaluacja w swej uspołecznionej i dialogicznej formie może się więc stać animatorem tworzenia wspólnoty akademickiej, inspiratorem innowacji w zakresie kultury zarządzania, a nawet może przyczynić się do wykreowania kulturotwórczej misji uczelni jako środowiska rozwoju indywidualnego i społecznego absolwentów. Wszystkie te cele są możliwe do osiągnięcia pod warunkiem właściwego rozumienia istoty ewaluacji, jej funkcji i metodologii stosowania. Tylko wtedy możliwe jest prowadzenie uspołecznionego procesu o charakterze wspierającym. Wymaga to jednak czasem odmiennego aplikowania badań ewaluacyjnych niż te określone przepisami ustawy z dnia 20 lipca 2018 r. - Prawo o szkolnictwie wyższym i nauce.

\section{BIBLIOGRAFIA}

Dańda A., Szkup B., Banaszak B., Wiewiór P., Wawer Ł., Rojek M., Ewaluacja jakości działalności naukowej - przewodnik, https://sum.edu.pl/images/wiadomosci18/20181114_PRZEWODNIK_O_EWALUACJI.pdf [dostęp: 10.10.2019].

Guba E.G., Lincoln Y.S., Fourth Generation Evaluation, London 1989.

Jaskuła S., Ewaluacja społeczna w edukacji, Kraków 2018.

Jaskuła S., Społeczne zharmonizowanie ewaluacji, „Seminare” 2018, nr 3, DOI: http:// doi.org/10.21852/sem.2018.3.10.

Kierzkowski T., Ocena (ewaluacja) programów i projektów o charakterze społeczno-gospodarczym w kontekście przystapienia Polski do Unii Europejskiej, Warszawa 2002.

Korporowicz L., Interakcyjna misja ewaluacji, [w:] Ewaluacja w nadzorze pedagogicznym. Konteksty, red. G. Mazurkiewicz, Kraków 2010.

Lutyński J., Działania pozorne, „Kultura i Społeczeństwo” 1977, nr 2.

Lutyński J., Nauka i polskie problemy. Komentarz socjologa, Warszawa 1990.

Ornacka K., Procedura ewaluacyjna a standardy ustug w pomocy spotecznej: praca socjalna z rodzina dotknięta zjawiskiem przemocy oraz interwencja kryzysowa w rodzinie dotkniętej zjawiskiem przemocy, www.wrzos.org.pl/projekt1.18/download/ Ekspertyza\%20ZE\%20PwR.pdf [dostęp: 4.05.2019].

Ossowski S., O osobliwości nauk społecznych, Warszawa 2001. 
Rozporządzenie Ministra Edukacji Narodowej i Sportu z dnia 23 kwietnia 2004 roku w sprawie szczegółowych zasad sprawowania nadzoru pedagogicznego, wykazu stanowisk wymagających kwalifikacji pedagogicznych, kwalifikacji niezbędnych do sprawowania nadzoru pedagogicznego, a także kwalifikacji osób, którym można zlecać prowadzenie badań i opracowywanie ekspertyz (Dz.U. 2004, nr 89, poz. 845). Rozporządzenie Ministra Edukacji Narodowej z dnia 7 października 2009 roku w sprawie nadzoru pedagogicznego (Dz.U. 2009, nr 168, poz. 1324).

Szacka B., Wprowadzenie do socjologii, Warszawa 2003.

Szkoła wyższa w toku zmian. Diagnozy i konstatacje, red. J. Kostkiewicz, A. Domagała-Kręcioch, M.J. Szymański, Kraków 2011.

Sztompka P., Socjologia. Analiza spoteczeństwa, Kraków 2002.

Tyler R.W., Smith E.R., Appraising and Recording Student Progress, Vol. 3: Adventure in American Education, New York 1942.

Ustawa z dnia 20 lipca 2018 roku - Prawo o szkolnictwie wyższym i nauce (Dz.U. 2018, poz. 1668).

Summary: In Polish conditions, in many areas, evaluation departs from its more than 100-year-old tradition of social applied research, whose main purpose is to support development. The term "evaluation" is often overused, and a tendency to replace other diagnostic methods, such as measurement, parameterization, accreditation, audit or assessment, with this term is noticed. Control and bureaucratic functions are unjustly attributed to evaluation, while omitting its animation, socializing, motivational and formative potentials. In this way, evaluation loses its reliability and takes the form of sham activities, that is, those which do not achieve the assumed goals, or do not fulfill the assumed functions, although they are carried out in accordance with the intentions of parties.

Keywords: social evaluation; sham activities; apparent evaluation; evaluation in education; evaluation of the quality of education 